\title{
Characterisation of porous coatings formed on titanium under DC plasma electrolytic oxidation
}

\author{
Krzysztof Rokosz ${ }^{1, *}$, Tadeusz Hryniewicz ${ }^{1}$, Sofia Gaiaschi' $^{2}$, Patrick Chapon $^{2}$, Steinar \\ Raaen $^{3}$, Lukasz Dudek ${ }^{1}$, Kornel Pietrzak ${ }^{1}$, Winfried Malorny ${ }^{4}$ and Radion Ciuperca ${ }^{5}$ \\ ${ }^{1}$ Division of BioEngineering and Surface Electrochemistry, Department of Engineering and \\ Informatics Systems, Faculty of Mechanical Engineering, Koszalin University of Technology, \\ Racławicka 15-17, PL 75-620 Koszalin, Poland \\ ${ }^{2}$ HORIBA Jobin Yvon S.A.S., Avenue de la Vauve - Passage Jobin Yvon, CS 45002 - 91120 \\ Palaiseau, France \\ ${ }^{3}$ Department of Physics, Norwegian University of Science and Technology (NTNU), Realfagbygget \\ E3-124 Høgskoleringen 5, NO 7491 Trondheim, Norway \\ ${ }^{4}$ Hochschule Wismar-University of Applied Sciences Technology, Business and Design, Faculty of \\ Engineering, DE 23966 Wismar, Germany \\ ${ }^{5}$ Manufacturing Engineering, Technical University of Moldova, str. Studenţilor, 9/8, blocul de studii \\ nr. 6, Chisinau, Republic of Moldova
}

\begin{abstract}
Porous coatings on titanium may be obtained by AC or DC Plasma Electrolytic Oxidation (PEO) process. One has to point out that depending on the plasma treatment the ranges of voltages used are different. It has been found that for DC PEO processing the voltage must be higher than that in the case of AC PEO treatment. In addition, the shape and frequency of the voltage signal have also an impact. Produced coatings were examined with scanning electron microscopy (SEM) with energy dispersive X-ray spectroscopy, X-ray photoelectron spectroscopy and glow discharge optical emission spectroscopy (GDEOS). It was found that it is possible to obtain the porous coatings enriched with phosphorus and copper by use of DC-PEO at 500, 575 and $650 \mathrm{VDC}$, whereas increasing the $\mathrm{PEO}$ voltage results in an increase of $\mathrm{Cu} / \mathrm{P}$ (copper-to-phosphorus) atomic ratio. Furthermore, based on GDEOS data, three sublayers with different elements concentrations were detected ranging as follows 0-350, 350-2100, 2100-2900 seconds of sputtering time for $575 \mathrm{~V}_{\mathrm{DC}}$. Based on XPS results the top $10 \mathrm{~nm}$ layer, consisted mainly of titanium $\left(\mathrm{Ti}^{4+}\right)$, copper $\left(\mathrm{Cu}^{+}\right.$ and/or $\left.\mathrm{Cu}^{2+}\right)$, and phosphates $\left(\mathrm{PO}_{4}^{3-}, \mathrm{HPO}_{4}{ }^{2-}, \mathrm{H}_{2} \mathrm{PO}_{4}^{-}, \mathrm{P}_{2} \mathrm{O}_{7}{ }^{3-}\right)$.
\end{abstract}

\section{Introduction}

Titanium and its alloys may be used as biomaterials. The electropolishing techniques [1-8] are used to obtain nanocoatings, while the micro coatings may be formed during the Plasma Electrolytic Oxidation (PEO), also known as Micro Arc Oxidation (MAO), on titanium [911] and its alloys [12-24]. The PEO coatings are mostly built of hydroxyapatite-like structure enriched with bactericidal copper [10,25-29]. The PEO coatings are produced at

\footnotetext{
*Corresponding author: rokosz@tu.koszalin.pl
} 
DC and AC voltages of several hundred volts; in addition it should be noted that errors related to the voltage instability as well as with the distortion associated with the shape of the wave are also affected [30-31]. They are from obtained by DC PEO processes with the use of concentrated phosphoric acid based electrolyte in different conditions were described in previous papers [32-37]. The aim of this work is to present results of studies of DC PEO process with the use of electrolyte based on concentrated phosphoric acid $\mathrm{H}_{3} \mathrm{PO}_{4}$ with the addition of copper nitrate trihydrate $\mathrm{Cu}\left(\mathrm{NO}_{2}\right)_{2} \cdot 3 \mathrm{H}_{2} \mathrm{O}$ to investigate effect of different voltages 500,575 and $650 \mathrm{~V}_{\mathrm{DC}}$ on the obtained coatings physical and chemical properties.

\section{Methods}

The CP Titanium Grade 2 samples with dimensions of $10 \mathrm{~mm} \times 10 \mathrm{~mm} \times 2 \mathrm{~mm}$ were treated by plasma electrolytic oxidation (PEO). The process was performed for $3 \mathrm{~min}$ at voltages of $500 \mathrm{~V}_{\mathrm{DC}}, 575 \mathrm{~V}_{\mathrm{DC}}$ and $650 \mathrm{~V}_{\mathrm{DC}}$ by using the commercial DC power supply PWR 1600H (KIKUSUI Electronics Corporation International, Yokohama, Kanagawa, Japan), 0-650V/0-8A. The electrolyte composition was the following: $1 \mathrm{~L}$ of $85 \%$ phosphoric acid $\mathrm{H}_{3} \mathrm{PO}_{4}$ with $500 \mathrm{~g}$ copper nitrate trihydrate $\mathrm{Cu}\left(\mathrm{NO}_{3}\right)_{2} \cdot 3 \mathrm{H}_{2} \mathrm{O}$. The instrumentations of SEM, EDS, GDOES, and XPS measuring systems were described earlier in $[18,20]$.

\section{Results and discussion}

In Figure 1, SEM micrographs of coatings formed on CP Titanium Grade 2 after DC PEO treatment at voltages $500,575,650 \mathrm{~V}_{\mathrm{DC}}$, are presented. The coatings obtained at voltages of 500,575 and $650 \mathrm{~V}_{\mathrm{DC}}$ may be characterized as porous with well-developed surfaces. However, the obtained morphologies differ one from another for different voltages.
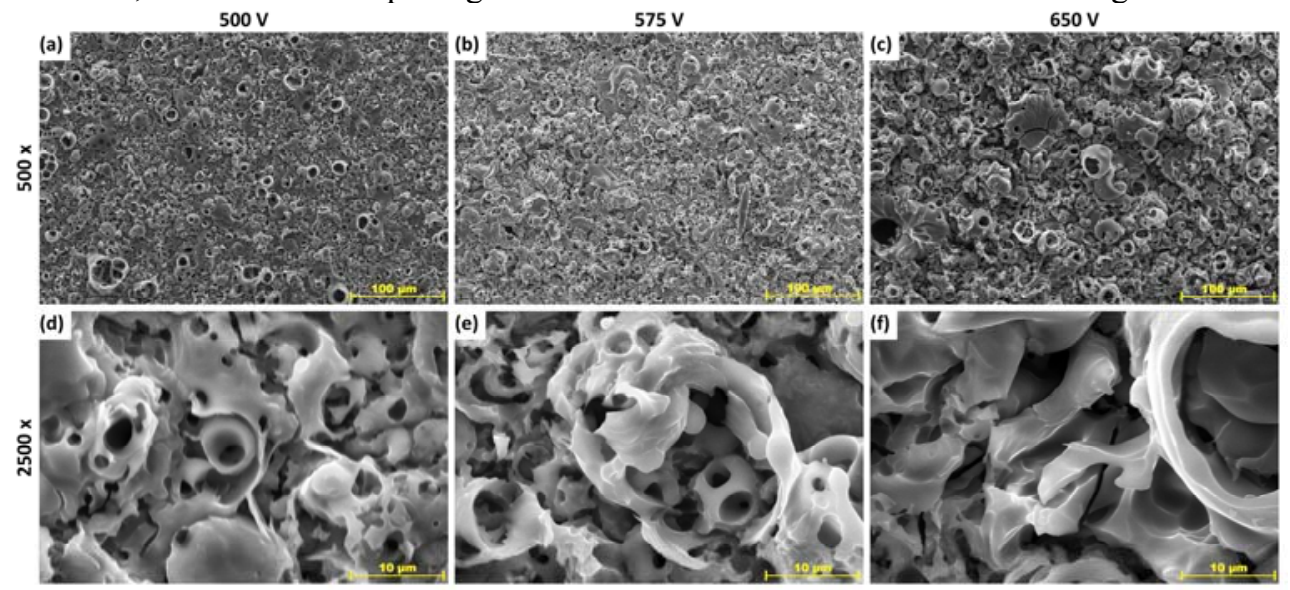

Fig. 1. SEM pictures of coatings formed on Titanium Grade 2 after DC PEO treatment at voltages of $500 V_{D C}, 575 V_{D C}, 650$ VDC. Magnifications 500 and 2500 times.

Pores observed on sample obtained at $500 \mathrm{~V}_{\mathrm{DC}}$ are more round and have more smooth edges, while those obtained at $650 \mathrm{~V}_{\mathrm{DC}}$ have other shapes and the edges are more sharp. It is also worth to note that $650 \mathrm{~V}_{\mathrm{DC}}$ sample has more solid inclusions and less uniform morphology (visible in Fig 1. (c)). Samples obtained at $575 \mathrm{~V}_{\mathrm{DC}}$ have some different, intermediate, between 500 and $650 \mathrm{~V}_{\mathrm{DC}}$, surface properties. The developed morphologies of coatings may be applied for biomaterials and catalysts. Based on EDS data from 5 records 
for each sample generated in magnification of 500 times for coatings formed on Titanium Grade 2 after DC PEO treatment at voltages of $500 \mathrm{~V}_{\mathrm{DC}}, 575 \mathrm{~V}_{\mathrm{DC}}, 650 \mathrm{~V}_{\mathrm{DC}}$ the $\mathrm{Cu} / \mathrm{P}$ atomic ratios were equal to $0.12 \pm 0.01$ (first quartile 0.11 ; third quartile 0.13 ), $0.16 \pm 0.02$ (first quartile 0.14; third quartile 0.17), $0.17 \pm 0.01$ (first quartile 0.16; third quartile 0.18), respectively. The $\mathrm{Cu} / \mathrm{P}$ value has a positive correlation with voltage that can be associated with plasma energy. In Figure 2, the GDEOS results for copper, phosphorus, oxygen, titanium, hydrogen, carbon, nitrogen of coatings obtained on CP Titanium Grade 2 after DC PEO treatment at the voltage of $575 \mathrm{~V}_{\mathrm{DC}}$, are presented. The presence of copper and phosphorus (major elements of coating originating from the electrolyte) as well as titanium (as the element of matrix) was described and proved by the higher presented EDS data. Based on GDOES results obtained (Figure 2) it was found that the coating can be divided into three sub-layers. The first sub-layer has open and organically contaminated from atmosphere pores, the second semi-porous one with lower concentrations of phosphorus, hydrogen, oxygen and carbon, and the third transition sub-layer in which phosphorus, oxygen, copper, nitrogen signals are decreasing whereas the titanium signal is increasing. The first, top sub-layer thickness refers to approximately $350 \mathrm{~s}$ of sputtering time. The second sub-layer is thicker than the first one and is referred to the range of approximately 350 up to $2100 \mathrm{~s}$, resulting in the thickness corresponding with $1750 \mathrm{~s}$ of sputtering time. The third transition sub-layer is referred to about $2900 \mathrm{~s}$ of sputtering time resulting in the thickness corresponding with $800 \mathrm{~s}$ of sputtering time. Local maxima of hydrogen and carbon signals can be considered as organic contamination coming from the air, which can be associated with the multi-pore structure that can be considered as a drug delivery system or catalyst matrix.

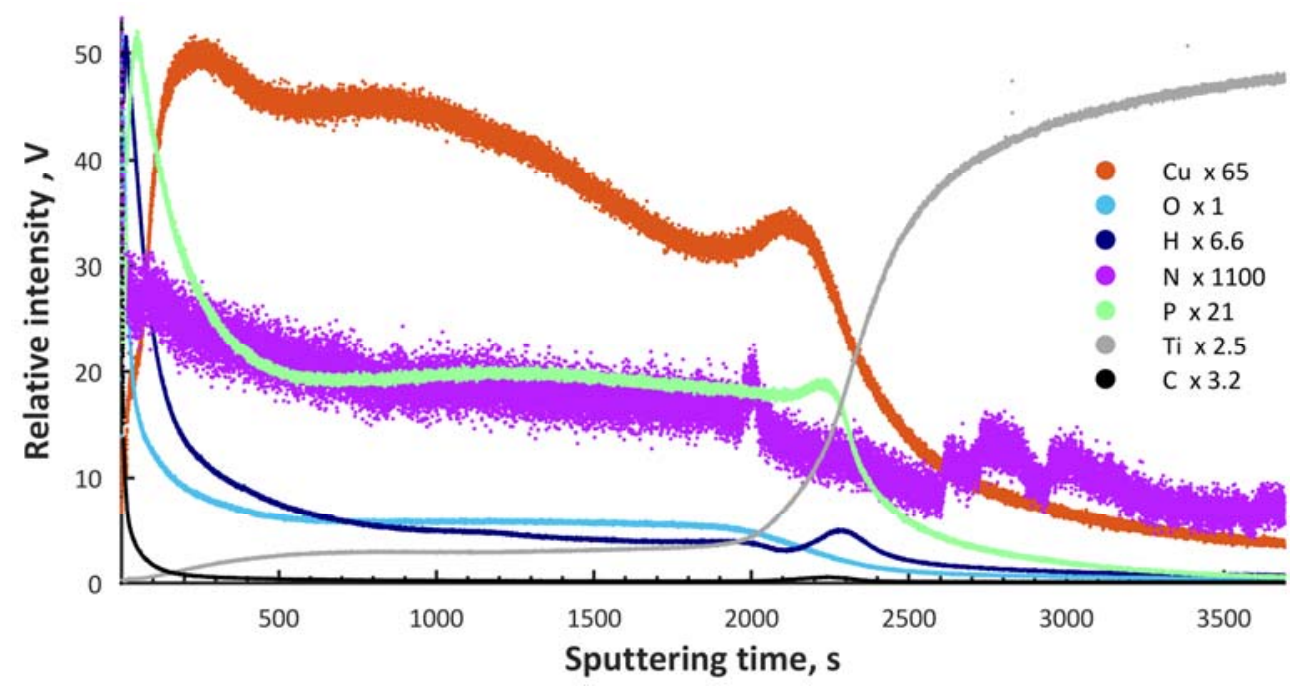

Fig. 2. GDEOS results for copper, phosphorous, oxygen, titanium, hydrogen, carbon, nitrogen, coatings formed on Titanium Grade 2 after DC PEO treatment at voltages of 575 VDC.

In Figure 3, XPS spectra of coatings formed on CP Titanium Grade 2 after DC PEO treatment at the voltage of $575 \mathrm{~V}_{\mathrm{DC}}$, are presented. The obtained XPS result clearly shows that the $10 \mathrm{~nm}$ top layer, consisting mainly of titanium $\left(\mathrm{Ti}^{4+}\right)$, copper $\left(\mathrm{Cu}^{+}\right.$and/or $\left.\mathrm{Cu}^{2+}\right)$, and phosphates $\left(\mathrm{PO}_{4}{ }^{3-}, \mathrm{HPO}_{4}{ }^{2-}, \mathrm{H}_{2} \mathrm{PO}_{4}^{--}, \mathrm{P}_{2} \mathrm{O}_{7}{ }^{3-}\right)$ may be confirmed by the binding energies, i.e. Ti $2 \mathrm{p}_{3 / 2}(460.5 \mathrm{eV}), \mathrm{Cu} 2 \mathrm{p}(935.8 \mathrm{eV}), \mathrm{O} 1 \mathrm{~s}(531.9 \mathrm{eV}), \mathrm{P} 2 \mathrm{p}(134.7 \mathrm{eV}), \mathrm{P} 2 \mathrm{~s}$ $(198.1 \mathrm{eV})$. In addition, nitrogen detected in the PEO coating can origin from nitrate ions present in the electrolyte as well as from the organic contaminations, that was observed in case of carbon and oxygen. 


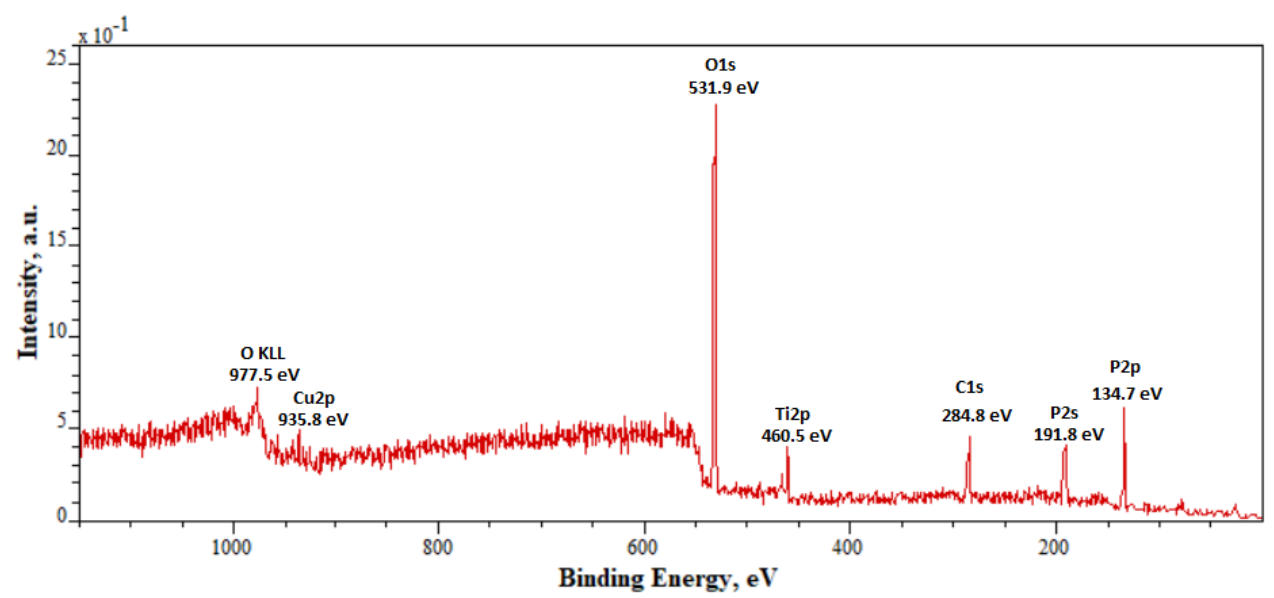

Fig. 3. XPS results for coatings formed on Titanium Grade 2 after DC PEO treatment at voltage of $575 \mathrm{VDC}$.

\section{Conclusions}

- It is possible to obtain the porous coatings enriched with phosphorus and copper by use of DC-PEO at 500, 575 and $650 \mathrm{VDC}$.

- Applied voltage has significant impact on pore shape, i.e. roundness and sharpness of the edges, the higher applied voltage, the less round pores and more sharp edges.

- The use of higher voltage results in increase of $\mathrm{Cu} / \mathrm{P}$ atomic ratio measured by EDS

- GDEOS data indicate the existence of three open-pore sub-layer structures.

- The top $10 \mathrm{~nm}$ layer of surface consists mainly of titanium $\left(\mathrm{T}^{\mathrm{i4}+}\right)$, copper $\left(\mathrm{Cu}^{+}\right.$and/or $\left.\mathrm{Cu}^{2+}\right)$ and phosphates $\left(\mathrm{PO}_{4}^{3-}, \mathrm{HPO}_{4}{ }^{2-}, \mathrm{H}_{2} \mathrm{PO}_{4}^{-}, \mathrm{P}_{2} \mathrm{O}_{7}{ }^{3-}\right)$, the presence of which are confirmed by the binding energies, i.e. Ti $2 \mathrm{p}_{3 / 2}(460.5 \mathrm{eV}), \mathrm{Cu} 2 \mathrm{p}(935.8 \mathrm{eV}), \mathrm{O} 1 \mathrm{~s}$ (531.9 eV), P 2p (134.7 eV), P 2s (198.1 eV).

- Presented porous structures have prospects for applications as drug delivery system, or catalyst matrix, or biomaterials.

This work was supported by a subsidy from Grant OPUS 11 of National Science Centre, Poland, with registration number 2016/21/B/ST8/01952, titled "Development of models of new porous coatings obtained on titanium by Plasma Electrolytic Oxidation in electrolytes containing phosphoric acid with addition of calcium, magnesium, copper and zinc nitrates".

\section{References}

1. K. Rokosz, T. Hryniewicz, Anti-Corros. Method. M. 61, 1, 57-64 (2014)

2. M. Kušnerová, J. Valíček, M. Harničárová, T. Hryniewicz, K. Rokosz, Z. Palková, V. Václavík, M. Řepka, M. Bendová, Meas. Sci. Rev. 13, 1, 1-6 (2013)

3. R. Rokicki, T. Hryniewicz, C. Pulletikurthi, K. Rokosz, N. Munroe, J. Mater. Eng. Perform. 24, 1634-1640 (2015)

4. K. Rokosz, T. Hryniewicz, Int. J. Mater. Res. 104, 12, 1223-1232 (2013)

5. K. Rokosz, T. Hryniewicz, S. Raaen, Teh. Vjesn. 21, 3, 533-538 (2014)

6. K. Rokosz, J. Lahtinen, T. Hryniewicz, S. Rzadkiewicz, Surf. Coat. Tech. 276, 516$520(2015)$ 
7. K. Rokosz, F. Simon, T. Hryniewicz, S. Rzadkiewicz, Surf. Interface Anal. 47, 1, 8792 (2015)

8. J. Valíček, M. Držík, T. Hryniewicz, M. Harničárová, K. Rokosz, M. Kušnerová, K. Barčová, D. Bražina, Meas. Sci. Rev. 12 (2012)

9. K. Rokosz, T. Hryniewicz, P. Chapon, S. Raaen, Ricardo Zschommler Sandim, H. J. Spectrosc. 2016, 1-7 (2016)

10. K. Rokosz, T. Hryniewicz, S. Raaen, P. Chapon, Ł. Dudek, Surf. Interface Anal. 49, 4, 303-315 (2017)

11. W. Simka, A. Iwaniak, G. Nawrat, A. Maciej, J. Michalska, K. Radwański, J. Gazdowicz, Electrochim. Acta 54, 27, 6983-6988 (2009)

12. A. Kazek-Kęsik, J. Jaworska, M. Krok-Borkowicz, M. Gołda-Cępa, M. Pastusiak, M. Brzychczy-Włoch, E. Pamuła, A. Kotarba, W. Simka, Surf. Coat. Tech. 302, 158-165 (2016)

13. A. Krząkała, A. Kazek-Kęsik, W. Simka, RSC Adv. 3, 19725-19743 (2013)

14. A. Kazek-Kęsik, K. Kuna, W. Dec, M. Widziołek, G. Tylko, A. M. Osyczka, W. Simka, J. Biomed. Mater. Res B 104, 5, 903-913 (2016)

15. G. Dercz, W. Simka, A. Kazek-Kęsik, A. Maciej, S. Ogierman, Sol. St. Phen 227, 531-534 (2015)

16. A. Krzạkała, J. Młyński, G. Dercz, J. Michalska, A. Maciej, Ł. Nieuzyła, W. Simka, Archives of Metallurgy and Materials 59, 1, 199-204 (2014)

17. A. Kazek-Kęsik, K. Pietryga, M. Basiaga, A. Blacha-Grzechnik, G. Dercz, I. Kalemba-Rec, E. Pamuła, W. Simka, Surf. Coat. Tech. 328, 1-12 (2017)

18. K. Rokosz, T. Hryniewicz, S. Raaen, P. Chapon, Int. J. Adv. Manuf. Technol. 87, 912, 3497-3512 (2016)

19. K. Rokosz, T. Hryniewicz, S. Raaen, Int. J. Adv. Manuf. Technol. 85, 9-12, 24252437 (2016)

20. K. Rokosz, T. Hryniewicz, S. Raaen, P. Chapon, F. Prima, Int. J. Adv. Manuf. Technol. 89, 2953-2965 (2017)

21. K. Rokosz, T. Hryniewicz, S. Raaen, Teh. Vjesn. 24, 1, 193-198 (2017)

22. A. Kazek-Kęsik, G. Dercz, I. Kalemba, K. Suchanek, A.I. Kukharenko, D.M. Korotin, J. Michalska, A. Krzạkała, J. Piotrowski, E.Z. Kurmaev, S.O. Cholakh, W. Simka, Mat. Sci. Eng. C 39, 1, 259-272 (2014)

23. A. Kazek-Kęsik, D. Łastówka, A. Donesz-Sikorska, G. Dercz, W. Simka, J. Electrochem. Soc. 162, D589-D597 (2015)

24. A. Kazek-Kęsik, G. Dercz, K. Suchanek, I. Kalemba-Rec, J. Piotrowski, W. Simka, Surf. Coat. Tech. 276, 59-69 (2015)

25. K. Rokosz, T. Hryniewicz, Ł. Dudek, D. Matýsek, J. Valíček, M. Harničárová, J. Nanosci. Nanotechno. 16, 8, 7814-7817 (2016)

26. K. Rokosz, T. Hryniewicz, W. Malorny, Mater. Sci. Forum. 862, 86-95 (2016)

27. K. Rokosz, T. Hryniewicz, D. Matýsek, S. Raaen, J. Valíček, Ł. Dudek, M. Harničárová Materials 9, 5, 318 (2016)

28. K. Rokosz, T. Hryniewicz, S. Raaen, W. Malorny, Journal of Mechanical and Energy Engineering, 1, 41, 23-30 (2017)

29. J. Kolmas, E. Groszyk, D. Kwiatkowska-Rózycka, Substituted hydroxyapatites with antibacterial properties. Biomed. Res. Int. 2014 (2014) 
30. K. Zajkowski, Neural Computing and Applications 24, 2, $431-439$ (2014)

31. S. Duer, K. Zajkowski, I. Płocha, R. Duer, Neural. Comput. Appl. 22, 7, 1581-1590 (2013)

32. K. Rokosz, T. Hryniewicz, K. Pietrzak, P. Sadlak, J. Valíček, Adv. Mater. Sci. 17, 4, 55-67 (2017)

33. K. Rokosz, T. Hryniewicz, S. Gaiaschi, P. Chapon, S. Raaen, K. Pietrzak, W. Malorny, J. Salvador Fernandes, Metals 8, 112 (2018)

34. K. Rokosz, T. Hryniewicz, S. Gaiaschi, P. Chapon, S. Raaen, K. Pietrzak, Malorny, W. Metals 7, 354 (2017),

35. K. Rokosz, T. Hryniewicz, K. Pietrzak, W. Malorny, Adv. Mater. Sci. 17, 2, 41-54 (2017)

36. K. Rokosz, T. Hryniewicz, L. Dudek, W. Malorny, Adv. Mater. Sci 15, 3, 41-47 (2015)

37. K. Rokosz, T. Hryniewicz, L. Dudek, A. Schutz, J. Heeg, M. Winecke, Adv. Mater. Sci 16, 3, 15-25 (2016) 